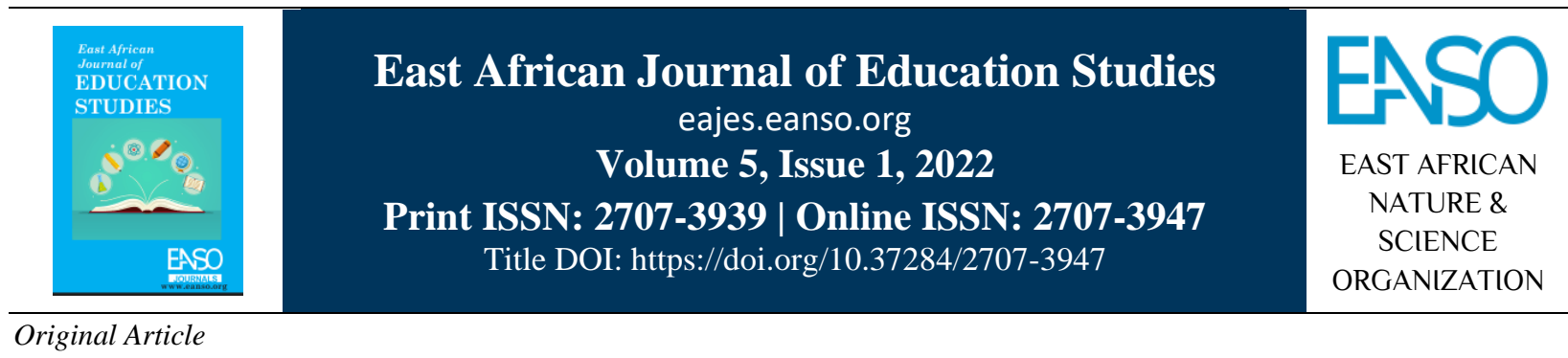

\title{
University Education, Good Governance and Challenges of Insecurity in Nigeria.
}

\author{
Dr. Stella Ofor-Douglas, $P h D, P h D^{1^{*}}$ \\ ${ }^{1}$ University of Port Harcourt, Rivers State, Nigeria. \\ * Author for Correspondence ORCID: https://orcid.org/0000-0002-6855-2106; Email: stellaofor031@ gmail.com.
}

Article DOI: https://doi.org/10.37284/eajes.5.1.555

\section{Date Published: ABSTRACT}

18 February 2022 Nigeria universities face numerous challenges, but this paper focuses on just two, which encompass the other challenges. Both the public and private

Keywords: universities in Nigeria face these issues and thus, it is of the essence that they

University Education, Good Governance, Insecurity. are brought to light and expounded upon. Hence, this paper delves into the issue of good governance and insecurity in Nigerian universities, and it also involves how education or the lack of good university education thereof can result in the aforementioned issues that will later plague universities. This brings about a dangerous cycle that would have no easy fix unless the issues are examined independently and linked subsequently. A brief examination of how these issues affect the progress of university education in Nigeria will be handled in a suitable introduction which will detail the reason why this study is essential and give a brief insight into the topical terms. The introduction will also include some objectives of the topic, which is what the paper intends to achieve in the process of its completion. An insightful look into the topical terms will be given with a follow-up of the relationship between the terms to give a complete understanding of the terms. A suitable literature review on the topical terms will be provided to give backing to the paper discussion, and solutions to the topical issues will be adduced thereafter. An applicable way forward to the topic will be provided to give a reader a practicable step to ensuring positive change as far as the topic is concerned.

\section{APA CITATION}

Ofor-Douglas, S. (2022). University Education, Good Governance and Challenges of Insecurity in Nigeria. East African Journal of Education Studies, 5(1), 54-65. https://doi.org/10.37284/eajes.5.1.555.

\section{CHICAGO CITATION}

Ofor-Douglas, Stella. 2022. "University Education, Good Governance and Challenges of Insecurity in Nigeria". East African Journal of Education Studies 5 (1), 54-65. https://doi.org/10.37284/eajes.5.1.555.

54 | This work is licensed under a Creative Commons Attribution 4.0 International License. 


\section{HARVARD CITATION}

Ofor-Douglas, S. \& Jules, R. (2022) "University Education, Good Governance and Challenges of Insecurity in Nigeria”, East African Journal of Education Studies, 5(1), pp. 54-65. doi: 10.37284/eajes.5.1.555.

\section{IEEE CITATION}

S. Ofor-Douglas, \& R. Jules, "University Education, Good Governance and Challenges of Insecurity in Nigeria", EAJES, vol. 5, no. 1, pp. 54-65, Feb. 2022.

\section{MLA CITATION}

Ofor-Douglas, Stella. "University Education, Good Governance and Challenges of Insecurity in Nigeria". East African Journal of Education Studies, Vol. 5, no. 1, Feb. 2022, pp. 54-65, doi:10.37284/eajes.5.1.555.

\section{INTRODUCTION}

The problems in Nigeria seems to be never-ending. This is so because despite identifying the areas that require change, nothing has been done to implement that change. As such, more problems arise from the previous ones, like a virus. As these problems abound more in society, it is up to the people in a nation to find solutions to them. Agitation for change is because of the ceaseless injustice, abuse of power and blatant disregard for the law in our society. The leaders who have been trusted with keeping the nation and its people secure as well as providing welfare have shown a lackadaisical attitude to governance. This attitude is a contributing factor to the increase in the rate of insecurity (Efeurhobo \& Fredrick, 2020). Other issues in society such as poverty, illiteracy, corruption, diseases etc., are also on the rise because of the failure to address the topical areas. It is the flagrant corruption, tribalism and constant disregard for the common man that cause the nation to keep falling. 'The lop-sidedness of the whole arrangement makes some segments of the society to be onlookers while others are busy accumulating what constitutionally belongs to all' (Efeurhobo \& Fredrick, 2020). This paper will therefore provide an examination of the topical areas of education, good governance, and insecurity to see their interrelationships and how if they are left unresolved, they will result in further problems that will leave the nation in ruins as they are prolonged.

\section{UNIVERSITY EDUCATION}

According to Alemu (2018), higher education is tertiary education leading to the award of an academic degree. Higher education, also called post-secondary education, third-level or tertiary education, is an optional final stage of formal learning that occurs after completion of secondary education. Higher education can thus be learning that takes place after secondary school. It is entered into with a goal of striving for an academic degree at the completion of a course of study. This degree can then be used to create pathways for employment in the workforce.

The university is a community of scholars and students engaged in a complex task of learning to which humanity looks up for overall human progress (Robert \& Worlu, 2013). Hamidu (2013) stated that education is the complete mental and physical transformation of a person(s) because of the structured model of training that the person(s) acquires to be productive in each society. Also, in the same vein, Olayanju (2014) upheld that education plays a critical role in human capacity building to have bright future needs to emphasise education because it is the only way to develop and the best legacy a nation can give to its citizens. Adegbesan (2011) opined that education contributes to individual development, increases their productivity and income at work and facilities the participation in economic and social life. University education is education at a higher level which can be followed up by more education if chosen. Consequently, education is the upbringing of people to know their environment and how they can contribute to the development of society (Ubi and Edet, 2013).

As seen in Prokhorov (1970), the training universities give students helps them to be ready for work in sectors of the economy. Also, the term "university education" has been opined by Prokhorov (1970) as "the totality of general and specialised knowledge and skills that enable a university graduate to solve problems that he encounters in industry or to perform scientific research or pedagogical work within the area of specialised knowledge that he has acquired". 
As maintained by Ofor-Douglas (2020b), university education has certain benefits to students and these include:

1) Giving students better opportunities in the following ways: -

- Individuals are required to have degrees for a wide range of careers such as medicine, education, engineering, accounting and law and the university provides for the obtainment of such degrees.

- University education will help an individual to succeed in today's workforce and establish an enjoyable career of his/her choice.

- The job market is extremely competitive and employers require the services of skilled employees to work for them. This skill can be developed in the university.

Education has so many benefits to an individual and in turn a nation if it is received in good quality and is practised effectively. It thus needs to be a priority amongst the government, the university administration, and the people of a nation.

\section{Good Governance}

Gradual global recognition of the need for good governance emerged only from the 1990s onwards. The term good governance is associated with various meanings, but it is usually used in parlance with political, economic, and social goals, which are requirements for obtaining development. 'Hence, good governance is the process whereby public institutions conduct public affairs and manage public resources in a manner that promotes the rule of law and the realisation of human rights (civil, political, economic, social, and cultural rights).'Despite available definitions of the term good governance, its meaning and scope are not always clear (UNODC, n.d.).

"According to the United Nations Office of the High Commissioner for Human Rights (OHCHR), the key question for assessing good governance is: Are the institutions of governance effectively guaranteeing the right to health, adequate housing, sufficient food, quality education, justice and personal security? (UNODC, n.d.)
In recent times the terms "governance" and "good governance" have been used greatly in societal development literature. Bad governance is greatly known as the root cause of all societal ills (UNESCAP, n.d.). The term governance is not a modern concept for it has been around in human civilisation. 'Governance means the process of decision-making and the process by which decisions are implemented (or not implemented).

Good governance can be seen as a "moral stance, a supreme value maximises" the common good" and is therefore to be pursued in public and private spheres, including civil society organisations (Cangas, 2014). The World Bank defines good governance in terms of the traditions and institutions by which authority in a country is exercised. This includes 1) the process by which governments are selected, monitored and replaced; 2) the capacity of the government to effectively formulate and implement sound policies; and 3) the respect of citizens and the state for the institutions that govern economic and social interactions among them (UNODC, n.d.). A good government looks out for its citizenry and all its actions reflect the needs of the people. Johnston, Michael (2002) defines good governance as "legitimate, accountable, and effective ways of obtaining and using public power and resources in the pursuit of widely accepted social goals". This definition links good governance with the rule of law, transparency and accountability and embodies partnerships between state and society and among citizens (UNODC, n.d.). A good government is thus backed up by the people's will and does what benefits them and society. Similarly, Susan Rose-Ackerman, and Bonnie J. Palifka (2016) suggests that good governance refers to "all kinds of institutional structures that promote both good substantive outcomes and public legitimacy" (UNODC, n.d.). A good government does not just involve those in federal or state positions but the leaders in an institution like the university.

\section{Features of Good Governance}

In the view of UNESCAP (n.d.), the concept of good governance has eight major characteristics, which are: participatory; consensus-oriented, accountable; transparent; responsible; effective and efficient; equitable and inclusive; and follows the rule of law 
Applying these characteristics to a government in our society, it is observable that one who follows these attributes would not only benefit the growth and development of a nation but ensure the prosperity of the members of the society. This in turn will increase international recognition and make the country an ideal to others. Tourism, trade, and increased business opportunities will follow such a nation. As such it is necessary to strive for these features of good governance for the benefit and welfare of a nation and its people.

\section{Effect of Bad Governance in University Education}

Lack of Motivation: In this situation, the lack of motivation will affect the staff of an institution and how that institution operates.

Unqualified Teachers: In a university that is led by bad governance, there will be a high turnover of staff as they would if the institution was led by a good government. Oyanna (2020) posits that many teachers are unprepared to use technology to support student learning as they lack the digital skills to effectively use technology in the classroom. The lack of qualified lecturers, especially those who use traditional methods, will reduce the standard of the university and leave students without the right guidance to grow in their field.

Lack of Critical Infrastructural facilities: A university run by a bad government will neglect to provide proper facilities for teaching and learning. This will severely limit the learning opportunity of the students. Adedigba (2020) maintains that there is no university in Nigeria that is approved by National Universities Commission to operate 100 per cent online learning, but a few private resources are taking advantage of classes online. He further said that most of the public universities and few private universities are not equipped for online learning as online classes are given in modulus and it requires expertise to develop the curriculum. All these infrastructures are vital and students missing out on them will create a gap between them and the students in private universities and even make things difficult for them when seeking employment because they will not be as skilled as those who had the right facilities to learn.

\section{Strategies to Achieve Good Governance in Nigerian Universities}

In Nigerian universities, various steps can be taken to achieve good governance that will improve the lives of every member of the university community and those related to it. Such strategies are not too far off from how an actual country is run because they all entail seeking the best for the people within it and promoting the self-growth of the body. In the view of Ekundayo and Ajayi (2009), the strategies to achieve good governance in Nigerian universities are as follows:

1) Improved and sufficient funding for running the university should be implemented. The government should allocate more funding to universities and ensure there is proper monitoring of how these funds are used to ensure the proper development of the university environment.

Improving the facilities in the university to be up to international standards. For students to learn efficiently, they should be in a safe, comfortable environment that has the requirements they need for their field of study. The other facilities in the university need to be reformed and properly maintained to ensure they last long. Ofor-Douglas (2020a) posits that adequate facilities should be provided in the university to dissuade students from engaging in all forms of protests, demonstrations, and violence on the campus.

Increasing the salaries of university staff which will motivate them to do their jobs more effectively. This will also attract bright minds to seek employment at a university that pays well.

Granting autonomy to universities is a necessity. This is so because of the usual interruptions of academic sessions due to the frequent tussles between ASUU and the government which affect students' progress in the university. This autonomy will ensure more quality education. Varma (1967) in Babalola et al. (2007) argued that for a university to be truly autonomous, the state control must be minimum, limited to requirements of proper utilisation of funds and conformity to the broad objectives of national policy. This implies that although university autonomy is necessary, it should not be completely severe some assistance 
from the government. These aspects of autonomy need the government and university stakeholders to agree on them.

Restructuring of the way universities is run to improve their performance and ensure they operate according to their role in the society which is to shape the lives and characters of students through quality and standard education.

To reduce violent student unionism and militant activities, students need to be more involved in decision making that concerns them. Mgbekem (2007) as seen in Ekundayo and Ajayi (2009), suggested the following as means of curbing students' crises:

University administrators should avoid being highhanded with students.

Vice-chancellors should make themselves accessible to students.

University administrator should establish frequent forums for negotiation, dialoguing and exchanging of ideas between students and university administrators".

Fighting against secret cults is necessary to increase security in Nigerian universities. The combined efforts of 'government, university authority, religious leaders, students and parents are required to ensure complete eradication of cultism and increase security and peace in the university.

Removing political interference from the activities of Nigerian universities. This would ensure that those appointed in key positions in the university are there based on their qualification and not on tribalism or nepotism.

\section{Consequences of Bad Governance}

A bad government is one whose leadership is in question as to the effectiveness of its rule. A bad government does not focus on the needs of the people and their actions lead to a disintegration of societal peace. In a country where care is not taken by the government to put the people first and leave out corrupt or inefficient attitudes that affect the growth and reputation of such a country, there will be consequences to that effect. Some of these consequences include:

- Discouraging patriotism

- Breakdown of the Economy

- Anarchy and rebellion

- Brain drains

- Weak Political /Governmental Structures

- Encouragement of a distrustful attitude towards government institutions

\section{Solutions to Bad Governance in Africa}

Having highlighted the reasons behind bad governance and the consequences, this article will attempt to recommend possible solutions which should also be considered feasible as well. According to Chukwuemeka (n.d.), some solutions to bad governance are as follows:

1) Governments should improve in their accountability

Transparency should be increased amongst the government and its establishments.

There should be established institutions to train future leaders

Increased measures should be taken to end corrupt practices in the country.

There should be increased reverence for the fundamental human rights

There should be no tolerance for any corrupt practices and inefficient or incompetent leaders.

\section{Security}

According to Ezeoha (2011) as cited by Oden (2022), security means stability and continuity of livelihood, predictability of relationships, feeling safe and belonging to a social group. Security can entail a state of being sure that there are no worries and every situation remains in the same peaceful state. As opined by Brown (2013) cited in. Omoroje et al. (2020), national security is the ability to 
preserve the nation's physical integrity and territory, to maintain its economic relations with the rest of the world on reasonable terms, to preserve its nature, institutions and governance from outside disruption, and to control its borders. Gbletan and Azih (2016) cited in Ofor-Douglas (2019) affirmed that some indications of insecurity imply a state of vulnerability to attacks, danger or threat to a people their properties, cherished values and the inability of the nation to protect its citizenry.

Sanda (2014) upheld that the concept of security is a cross-cutting and multi-dimensional concept that has overtaken the last century been the subject of great debate. Thus, no singular definition exists for the term security although the definitions provided seem to have a similar message. Ofor-Douglas (2019) buttressed that the aim of refocusing security in universities is to ensure quality university education in a peaceful atmosphere. Ensuring security in universities should be a top priority because it furthers better education and can dissuade criminal actions from those who have experienced it before. Ejdus and Savkovic (2011) affirm that security is an abstract idea about the norms and values underlining the legitimacy of (national) policies and actors involved in the national pursuit of freedom from threats. Providing security is thus the government's duty for the well-being and progress of the people and society. Salau (2012) views security as the absolute guarantee that people enjoy under a nation or state in terms of comfortability and operation without with-out fear or threat. Security gives a sense of normalcy and affects how people act in society. A secure environment provides a condition of feeling safe from harm, danger or peril or absence of a threat of any kind (Pinga, 2014).

Security embraces all measures designed to protect and safeguard the citizenry and the resources of individuals, groups, businesses and the nation against sabotage or violent occurrences (Ogunleye et al., 2011). Igbuzor (2010) maintains that security places individuals at the centre of the security equation, thereby bringing the concept of human security which combine elements of national security, economic development, and basic human rights. Security is a feeling people require to live freely and productively and as such, it should be treated as a priority. Akin (2008) as cited in Dorgu
(2020), affirms that security as the situation that exists because of the establishment of measures for the protection of persons, information and property against hostile persons, influences, and actions. Omoyibo and Akpomera (2012) view security as a concept that is prior to the state, and the state exists to provide that concept. Igbuzor (2010) submits that security is the condition or feeling of safety from harm or danger, the defence, protection and preservation of core values and the absence of threats to these values. It is the absolute guarantee that people enjoy under a nation or state in terms of comfortability and operation without fear or threat.

Katsina (2012) views security as a state of reduced or contained threats and tension in which the stability of a state is not in any imminent danger of disruption from within or without. Similarly, Ejdus and Savkovic (2011) affirm that security is an abstract idea about the norms and values underlining the legitimacy of (national) policies and actors involved in the national pursuit of freedom from threats. Salau (2012) is of the opinion that it is the absolute guarantee that people enjoy under a nation or state in terms of comfortability and operation without fear or threat. Again, it embraces all measures designed to protect and safeguard the citizenry and the resources of individuals, groups, businesses and the nation against sabotage or violent occurrences (Ognleye et al., 2011).

In the same vein, Igbuzor (2010) acknowledged that security places individuals at the centre of the security equation, thereby bringing the concept of human security which combines elements of national security, economic development, and basic human rights. Akin (2008) as cited in Dorgu affirms that security as the situation that exists because of the establishment of measures for the protection of persons, information and property against hostile persons, influences, and actions. Omoyibo and Akpomera (2012) emphasised that security is a concept that is prior to the state, and the state exists in order to provide that concept.

\section{Insecurity}

The concept of insecurity connotes different meanings such as the absence of safety, danger, hazard, uncertainty, lack of protection, and lack of safety and lack of safety (Ewetan and Urhie, 2014). 
In the same vein, Oyebamiji in Nsirim-Ovu (2016) maintains that violent conflict, otherwise known as the state of insecurity, could also be caused by; interest, bad leadership, willingness to enhance concession, discrimination, denial of one's right and justice, a breach in communication and so on. Katsina (2012) upheld that insecurity includes poverty among the citizenry which has resulted in a threat to humans and attributed to lack of good governance and transparency in leadership. High profile corruption, as witnessed in official places today is the direct product of bad governance and dishonesty in leadership. This sad development has in turn generated the absence of basic amenities for the provision of good and affordable houses for shelter, education, water, electricity, good roads, good transport system etc. Zumve and Torbunde (2015) view insecurity as a lack of security to lives and prosperity, justice and respect for lives and lack of basic needs such as food, water, shelter, and health. Achumba et al. (2013) sees insecurity from two perspectives. Firstly, insecurity is the state of being open or subject to danger or threat of danger, where danger is the condition of being susceptible to harm or injury; secondly, insecurity is the state of being 'exposed to risk or anxiety, where anxiety is a vague unpleasant emotion that is experienced in anticipation of some misfortune.

Consequently, Ofor-Douglas (2020) submits that security is another challenge faced by university education in Nigeria. It is common knowledge that where there is peace, there is progress. But in a situation whereby peace does not exist, and insecurity is the order of the day, there will be complete and utter disruption of the environment. This occurs in most universities where cultism, riots, fights, robbery, rape, and other forms of insecurity take place. Staff and students do not feel safe when these things occur, and thus, the activities within the university (academic and Non-academic) are disrupted. Katsina (2012) upheld that insecurity is because of entrenched structural crises of development and poverty that creates an environment for the emergence of poverty, unemployment, and inequality in the country. Again, Azih and Nwagwu (2015) opine on some of the causes of insecurity in Nigeria. These are high levels of unemployment, poor leadership, high level of moral decadence, religious fanaticism, poor quality of education, inadequate provision of welfare package, lack of spirit of patriotism, high level of poverty, the negative effect of foreign culture and poor parenting upbringing.

\section{Insecurity in Universities}

Insecurity in universities can have several causes. Sometimes the refusal of the university administration to listen to the needs of the students can cause them to protest and these protests may not always be peaceful leading to insecurity on the campus. Njoku (2015) maintained that the following critical incidents that can lead to protest by students: bomb blasts, cult killings, fire explosion with injuries or significant damage, infection diseases, missing students, mental health crises, extortion by teachers (lecturers), drug alcohol, sexual assault, death of a student's (on or off campus), significant injury on a student, mass exodus of teachers, less preference for teacher education, fewer female, teachers in primary, secondary and colleges of education, few female and males in some programmes. Bad governance on the part of the university administration can thus lead to insecurity on the campus. Ofor-Douglas (2019) further enunciated the forms of insecurity in Nigerian universities that are rampant including cultism, riot rape, students-community clashes kidnapping of lecturers and students etc. In addition to inadequate facilities, hostels, libraries, etc., issues of carrying capacity, where universities are over admitting students for their own gain to make more money for the school at the expense of the students, not giving the students his/her chosen course upon admission, issues of bribery and corruption, admission racketeering, exchange of scores, etc by lecturers and non- academic staff. Any discomfort caused as a result of bad governance in the university which affects both students and staff will be met with equivalent calls for change in form of protests, strikes etc.

\section{Causes of Insecurity}

In the view of Udoh (2015), insecurity is the state of being subject to danger or injury. The anxiety that is experienced when one feels vulnerable and insecure. Insecurity can thus be seen as a state of uncertainty or fear for safety. Akintokunbo (2011) as seen in Is'haq et al. (2019), connects insecurity in Nigeria to massive and unchecked corruption, 
greed, selfishness, unpatriotic, lack of political will and conscience, and of course, lack of vision and purpose. King (2016) as seen in Is'haq et al. (2019), views the causes of insecurity in Nigeria to be a blend of the following: lack of institutional capacity, lack of necessities, pervasive material inequalities and unfairness, ethno-religious conflicts, weak security system, loss of socio-cultural and communal value system, porous borders, rural/urban drift, anti-social and irresponsible companies, unemployment, and poverty.

In the view of Udoh (2015), the causes of insecurity include porous borders that allow criminals to enter into the country indiscriminately; ease of proliferating arms and ammunition illegally for criminals; peaceful protests for change in Nigeria keep being hijacked by thugs and miscreants; kidnapping; oil bunkering; militancy; lack of government transparency and inability to guarantee the safety of the nation's citizens; increase the rate of unemployment; religious extremists who will go through any means to get their agenda across usually resulting in loss of life; selfish political agendas which only fund the lifestyles of those in office; elections aren't conducted fairly at times and are usually characterized by corruption; thuggery, violence, and fear; tribalism, etc. Enoh (2014) affirms that when one is deprived of education, the products of science become dangerous weapons, thereby enhancing human vices disrupting peace and security. The lack of good quality education can lead one down the path of criminality and such a person will make use of available resources to get what they want.

\section{Causes of Security Challenges}

Okafor (2011) opined that unemployment in Nigeria is within attendant social, economic, political, and psychological consequences. The social consequences on the Nigerian youth are the high level of youth unemployment. Similarly, Enoh (2014) affirms that when one is deprived of education, the products of science become dangerous weapons, thereby enhancing human vices disrupting peace and security.

\section{Challenges of Insecurity in Nigeria}

Katsina (2012) is of the opinion that insecurity includes poverty among the citizenry which has resulted in a threat to humans and attributed to a lack of good governance and transparency in leadership. High-profile corruption, as witnessed in official places today is the direct product of bad governance and dishonesty in leadership. This sad development has in turn generated the absence of basic amenities for the provision of good and affordable houses for shelter, education, water, electricity, good roads, good transport system, etc.

\section{Effects of Insecurity in Nigeria}

As has been previously discussed, insecurity can cause a great deal of harm to the people of a nation in terms of their physical and mental health and livelihood. All these security challenges amount to some threats to the social, economic, and political stability of not only Nigeria but also the African continent, especially the West African sub-region, where more than half the population comes from Nigeria (Dambazua, 2014). Omoroje et al. (2020) opine that the effects of insecurity in Nigeria include.

1) Unemployment rate is increasing in states that are highly insecure which has led to an increased poverty rate as well.

A shadow of fear in communities affects the younger generation's perspective on hope and happiness in life.

Loss of foreign investments in Nigerian businesses

Tourism prospects will no longer be available.

Expatriates will no longer be interested in coming to an insecure country.

Foreign companies will no longer desire to set up branches in an insecure country.

Terrorism in some states has halted education and religious activities which destabilises the society and progress of the youth in life. 


\section{Relationship between Insecurity, Good Governance, and University Education}

From the topical terms which have been discussed previously, there can be an established relationship. Education and insecurity are linked because good quality education can help deter actions that result in insecurity. The education need not be formal education received in universities, but even good advice at home, sermons in places of worship, seminars, workshops, retreats, etc which the youth partake in can build their character to steer clear of acts that lead to an insecure state. Nandi (2013), as seen in Omoroje et al. (2020), opines that education helps in developing intelligent social actors with the ability to make rational decisions and act intelligently. Education can encourage youths to be self-independent and build livelihoods for themselves instead of resorting to criminal acts to escape poverty UNESCO (2008) as cited in Omoroje et al. (2020) posited that "No development can be possible without humans, and no humans can reach development without quality education".

It is the effort of the government to provide good quality education and a safe space to receive such education. It is with the effort of parents to shower their children with love and advice that will shape good characters in the future. It is the job of university staff to deliver the best education to their students so they grow up to be responsible leaders in the future. Dike (2003) as seen in Is'haq et al. (2019), maintains that the socio-political and economic development of a nation and or her health is in many ways determined by the quality and level of educational attainment of the population. Good and quality education will lead to a class of citizens that are hardworking and innovative and as such will contribute to the massive economic growth of a nation. Good governance, on the other hand, is responsible for education and as such can lead to insecurity if imbalanced. This is so because it is the government that can provide free or affordable quality education for its citizens. It is also the government's duty to ensure the security and welfare of the people of a nation. If this is done accordingly, the rate of insecurity will be reduced drastically. The government is thus a good starting point for change in the society as a good government will ensure there is little to no insecurity and that the education sector receives a healthy budget. It is thus essential that the concepts of good governance, university education and insecurity are addressed because if one aspect is neglected, the others will suffer.

\section{CONCLUSION}

Having discussed the interrelationships between education, good governance, and insecurity, solving the issue in this link would be key to bringing needed change to the nation and moving the country and its citizens to greater heights. As such, some restructuring needs to be implemented in the areas of focus. This restructuring can only be activated by those who have the power to do so such as the government and the university administrators. With their active participation in driving change in education, the security of the state, and the proud good governance of the nation, citizens of the nation will also be encouraged to play their part in that goal. The topic of this paper is therefore not a joke that should be dismissed as it focuses on subjects that affect the entire nation.

\section{Suggestions}

As a result of this study, it has been elucidated that education needs to be improved to bring an end to insecurity and encourage good governance. Some recommendations are thus made available to provide practical solutions to the topical issues based on the foregoing discussion. They are as follows:

1) The government at all levels needs to improve their efficiency and show that they value education and the people of a nation by prioritising education. This will ensure a change in the educational system and eradicate insecurity if they are focused on it.

Eradication of tribalism, ethnic and religious discrimination in public and private sectors, institutions and processes of the nation will ensure productivity and progress.

The government should focus on increased budgets for areas of security, education, and good governance. They should also follow up on the allocations to these sectors to ensure they are being use for the benefit of the citizens. 
Increasing education of youths on the effects of partaking in activities that cause insecurity so they would be discouraged from engaging in it no matter what their station in life is.

The government needs to actively ensure the proper rehabilitation of youths prone to criminal activities so they can become better for society.

The government needs to implement laws that will bring about productive change for all in the society and not just the privileged few.

University administrators need to make changes to how their universities are run and check in to see the students get a good experience and personal growth in the university environment

Skill acquisition programs need to be prioritised in university to build the students with values and vocational skills that will help them be self-reliant and productive members of society.

The government needs to provide more free facilities like scholarships, housing, food, healthcare, etc., to ensure the people of the nation are well catered for. This will discourage violent and criminal activities that threaten the peace and progress of the nation and its people.

The government needs to ensure stricter punishment is made for criminals and they are implemented to ensure the safety of the society and discourage others from becoming criminals.

The government needs to follow the standards of international bodies and countries that are experts in the topical areas and practical use them to change the country for the better.

\section{REFERENCES}

Achumba, I. C., Ighomereho, O. S., \& AkporRobaro, M. O. M. (2013). Security challenges in Nigeria and the implications for business activities and sustainable development. Journal of economics and sustainable development, 4(2), 79-99.

Adedigba, A. (2020, June 3). Nigeria grants approval to 12 universities to operate open distance learning. Premium Times. https://www.premiumtimesng.com/news/top- news/395983-nigeria-grants-approval-to-12universities-to-operate-open-distancelearning.html

Adegbesan, S. O. (2011). Establishing quality assurance in Nigerian education system: Implication for educational managers. Educational research and Reviews, 6(2), 147-151.

Alemu, S. K. (2018). The Meaning, Idea and History of University/Higher Education in Africa: A Brief Literature Review. In FIRE: Forum for International Research in Education (Vol. 4, No. 3, pp. 210-227). Lehigh University Library and Technology Services.

Azih, N., \& Nwagwu, L. (2015). Repositioning business education for alleviating insecurity in Nigeria: Business educators' perspective. Nigeria Journal of business education, 2(2), 19-30.

Babalola, J. B., Jaiyeoba, A. O. \& Okediran, A. (2007). University autonomy and financial reforms in Nigeria: historical background, issues, and recommendations from experience. In J. B. Babalola and B. O. Emenemu (eds), Issues in higher education: Research evidence from sub-sahara Africa. Lagos: Bolabay Publications.

Cangas, A. H. (2004). The good governance agenda of civil society. In Implications for $A C P-E U$ cooperation. European Centre for Development Policy Management.

Chukwuemeka, E. S. (n.d.). Bad Governance in Africa: Causes, Effects \& Solutions. Bscholarly LLC. https://bscholarly.com/bad-governancein-

africa/\#Effects_of_bad_Governance_Africa_as _a_case_study

Dambazau, A. (2014). The weatherhead center presents... Nigeria and her security challenges. Harvard International Review, 6570.

Dorgu, T. (2020). Curriculum innovation in nigeria higher institutions. Journal of Curriculum and Instruction, 13(1), 113-119.

63 This work is licensed under a Creative Commons Attribution 4.0 International License. 
Efeurhobo, D., \& Fredrick, C. (2020). Restructuring, Insecurity, and the Challenges of Development in Nigeria. UJAH: Unizik Journal of Arts and Humanities, 21(4), 155-170.

Ejdus, F.\& Savkovic, M. (2011). Emergent Concept of National Security Policy in Republic of Sebia, in Review of International Studies, 38, 2011.

Ekundayo, H. T., \& Ajayi, I. A. (2009). Towards effective management of university education in Nigeria. International NGO journal, 4(8), 342347.

Enoh, A.O. (2014). Education for All, Reponsibility of All: Analysis and Implications of A slogan. Journal of Education. 7(1), 1-10.

Ewetan, O. O., \& Urhie, E. (2014). Insecurity and socio-economic development in Nigeria. Journal of sustainable development studies, 5(1).

Hamidu, I. (2013). Students' poor performances in Nigeria: Critical issues, effects, problems, and prospects. International Journal of Social Sciences and Sustainable.

Igbuzor, O. (2011). Peace and security education: A critical factor for sustainable peace and national development. International journal of peace and development studies, 2(1), 1-7.

Is'haq, A. B, Musa, T. A. \& Abdulhafiz, Z. (2019). Education and Insecurity in Nigeria. https://www.researchgate.net/publication/33254 8880

Johnston, M. (2006). Good governance: Rule of law, transparency, and accountability. New York: United Nations Public Administration Network.

Njoku, C. U. (2015). Critical incidents in the Nigerian educational system: Challenges to business educators. Nigerian Journal of Business Education, 2(2), 1-17.

Nsirim-Ovu, H.D. (2016). Effect of Restiveness on Community Development in Ikwere andObio/Akpo Local Government Areas of Rivers State. Unpublished M.Ed Dissertation, University of Port Harcourt.
Oden, C. (2022). Causes and Effects of Insecurity in Nigeria: The Challenges and Relevance of the Nigerian Police Force as a Panacea. https://www.projecttopics.org/causes- effects- i nsecurity-nigeria-challenges-relevancenigerian-police-force-panacea.html/amp

Ofor-Douglas, S. (2020a). Conflict Management in University Education in Nigeria; A Catalyst for Peace. Al-Hikmah Journal of Educational Management and Counselling, Vol. 2(1), June 2020 (ISSN; 2695-2009) (E-ISSN; 2695-1991).

Ofor-Douglas, S. (2020b). University Education in Nigeria: The Challenges and Possible Solutions. In K. Achuonye, S. S. Shuaibu \& S. T. George (Eds), Issues, Challenges and Prospects of Higher Education in Nigeria. Onitsha: West and Solomon Publishing Coy Ltd.

Ogunleye, G. O., Adewale, O. S., Alese, B. K., \& Ogunde, A. O. (2011, July). A computer-based security framework for crime prevention in Nigeria. In A Paper presented at the 10th International Conference of the Nigeria computer society held from July 25th-29th. Nigeria Computer Society.

Okafor, E. E. (2011). Youth unemployment and implications for stability of democracy in Nigeria. Journal of sustainable Development in Africa, 13(1), 358-373.

Olayanju, O. J. (2014). Historical analysis of the implementation of teacher education policy in Nigeria: 1896-2013. International Journal of Special and General Education, 3, 131-154.

Omoroje, S. D., Egbule, P. O., \& Emuebie, J. E. (2020). Achieving National Security in Nigeria through Education. UJAH: Unizik Journal of Arts and Humanities, 21(4), 135-154.

Omoyibo, K. U., \& Akpomera, E. (2012). Insecurity mantra: The paradox of Nigerian growth and development. European Scientific Journal, 8(15), 132-142.

Oyanna, J. (2020). Covid-19: How technology is redefining the future of education. https://www.brainiacs.com.ng/categoni/e. 
Pinga, M. (2014). Influence of conflict between principals and teachers on the management of secondary schools in Makurdi Education Zone of Benue State. Unpublished Masters' Dissertation, Benue State University, Makurdi.

Prokhorov, A. M. (1970). Great Soviet Encyclopedia. New York: Macmillan.

Robert, O., \& Worlu, W. (2013). Deregulation of university education in Nigeria: Assessment of challenges and the way forward. In E. Kpangban, P. E. Eya \& P. C. Igbojinwaekwu (Eds), Reforms and Innovation in Nigerian Education. Onitsha: West and Solomon publishing company.

Rose-Ackerman, S. (2017). What does "governance" mean? Governance, 30(1), 23-27.

Salau, A. T. (2012). Terrorism and the Nigerian state.

Sanda, M. U. (2014). Peace education for economic development in African States: A theoretical and practices exercise. World Educators Forum 3 (1), 221-234.

Ubi, S., \& Edet, M. I. (2013). Globalisation and education in Nigeria. In A. Ejiogu, U. Uma \& R. Esene (Eds), Globalization and education in Nigeria. Onitsha-Nigeria: West and Solomon Corporate Ideals Ltd.

Udoh, E. W. (2015). Insecurity in Nigeria: political, religious and cultural implications. Journal of philosophy, culture and religion, 5, 1-7.

UNESCAP. (n.d.). What is Good Governance. United Nations Economic and Social Commission for Asia and the Pacific. https://www.unescap.org/sites/default/files/goo d-governance.pdf

UNODC. (n.d). Module 2: Corruption and Good Governance. United Nations Office of Drug and Crime. https://www.unodc.org/e4j/en/anti- corr uption/module-2/key-issues/what-is-goodgovernance.html

Zumve, S. I., \& Torbunde, C. (2015). Insecurity in contemporary Nigeria: Symptoms of a failing state. In Agwanwo, D. E. (Ed), A political economy of policing in Nigeria

$65 \mid$ This work is licensed under a Creative Commons Attribution 4.0 International License. 